JEFAS

27,53

86

Received 28 August 2020

Revised 16 June 2021

Accepted 31 July 2021

\section{Credit rating announcement and bond liquidity: the case of emerging bond markets}

\author{
Amir Saadaoui \\ Faculty of Economics and Management, University of Sfax, Sfax, Tunisia \\ Anis Elammari \\ Faculty of Economic Sciences and Management, University of Monastir, Mahdia, \\ Tunisia, and \\ Mohamed Kriaa \\ Faculty of Economics and Management, University of Sfax, Sfax, Tunisia
}

\begin{abstract}
Purpose - This study examines the effect of the informational content of local credit rating announcements in emerging markets on the liquidity of their bond markets. This study analyses the liquidity of bonds in various emerging bond markets using a sample of nine countries: Argentina, Mexico, Peru, Hungary, Poland, Spain, Turkey, Hong Kong and Greece. The sample includes daily data on sovereign bonds that go from July 2009 to July 2017. The main focus is on the period before and after the sovereign debt crisis. This study notes that the bond liquidity is affected due to the sign of the rating granted by the rating agencies for each country.

Design/methodology/approach - This study aims to question the sources of liquidity problem of sovereign bonds issued by the emerging countries. The study's database consists of daily data of all nine emerging countries for the period from July 2009 to July 2017. Panel data were collected from the Datastream database. Findings - This study first directly tests the information content of bond ratings announcements and their effect on bond market liquidity. Next, the impact of rating changes on sovereign bond liquidity around the rating announcements is studied. Rating changes can affect sovereign bond's price, trading and liquidity around the announcement date. In particular the rating changes that move the bonds out of the investment grade category can elicit selling pressure or even fire sale of the fallen angels.

Originality/value - This research aims to present data on the prices of sovereign bonds that react to changes in credit rating by studying the price movements around the announcement of changes in credit rating. The literature is very rich in studies on credit rating changes on stocks and corporate bonds, but this study is perhaps the first attempt on sovereign bonds.
\end{abstract}

Keywords Liquidity, Sovereign bond market, Credit ratings

Paper type Research paper

\section{Introduction}

The information extracted from the changed notes has been an appropriate issue in recent years. The ratings disclosed by the rating agencies do not contain complete information, being able to help investors. Unlike these agencies, the informational content is disclosed while transferring assessments without providing specific details to the public. Thus, the agencies' actions will have some effects on the market returns and asset prices.

\section{JEL Classification - C34, G15}

(C) Amir Saadaoui, Anis Elammari and Mohamed Kriaa. Published in Journal of Economics, Finance Journal of Economics, Finance and Administrative Science Vol. 27 No. 53, 2022 pp. 86-104

Emerald Publishing Limited e-ISSN: 2218-0648

p-ISSN: 2077-1886

DOI 10.1108/JEFAS-08-2020-0314 and Administrative Science. Published by Emerald Publishing Limited. This article is published under the Creative Commons Attribution (CC BY 4.0) licence. Anyone may reproduce, distribute, translate and create derivative works of this article (for both commercial and non-commercial purposes), subject to full attribution to the original publication and authors. The full terms of this licence maybe seen at http:// creativecommons.org/licences/by/4.0/legalcode 
Fridson and Sterling (2006) show that the credit rating agencies will summarize public information and that the changes in bond ratings do not transmit any new information to the market.

Recent studies have shown that negative rating announcements, especially reviews about decommissioning and downgrades, do not actually reflect information relevant to the pricing of shares, bonds and credit default swap (CDS) spreads (Chodnicka-Jaworska, 2017; Wengner et al., 2015). Overall, most of this literature estimates the price and/or returns. In this paper, we have moved further away from the traditional analysis of prices by looking into the effects of the rating agency's announcement on the liquidity of the emerging bond markets.

During recent years, sovereign ratings have been in the interest of research in the sovereign euro-zone, including Greece and Spain have experienced a drop in their ratings by Standard \& Poors (S\&P) in August 2011 (Andreasen and Valenzuela, 2016). The IMF, in its report of 2010, showed that the sovereign credit risk is one of the main obstacles to global economic stability. Consistent with this, Duggar et al. (2009) have found that $71 \%$ of business failures and under-rated sovereigns in the emerging markets have been improving during the sovereign crises.

Recent literature has shown that the changes in the sovereign rating and outlook/watch signals affect equity and emerging debt markets, respectively (Rusike and Alagidede, 2021). Indeed, it has also shown that these effects are not only significant at the national level since sovereign ratings are assigned to affect markets in other countries. In particular, the bad news has a negative effect that the new sovereign rating causes a significant impact on the equity and bond markets of other countries. However, the good news has a negligible effect (e.g. Böninghausen and Zabel, 2015). Banier and Hirsch (2010) have shown that these instruments were valued for providing a considerable economic benefit. Vazza et al. (2005) have analysed the behaviour of ratings of assets issued by companies and found that these issues have a higher probability of a rating change in the direction indicated.

In fact, Alsakka and Ap Gwilym (2009) have analysed the dynamics of the sovereign ratings for six rating agencies in the emerging economies, including status monitoring. They observed that the assets placed under surveillance have a higher probability of a rating change in the direction indicated by the status within 12 months after being placed on the watch list. Several studies prove that the sovereign ratings represent approximations of the ability and willingness of governments to highly regard their financial conditions. They also substantiate that these ratings capture the dynamics of capital markets and influence the capital cost.

Brooks et al. (2004) point out that the degradations of sovereign asset ratings have a large negative effect on the stock markets. Gande and Parsley (2005) and Ferreira and Gama (2007) reveal that the degradations of sovereign bond ratings - mainly during times of crisis aggregate stock returns of other countries, especially in the emerging economies and neighbouring countries, while the progressions of ratings have a ridiculous impact. Ismailescu and Kazemi (2010) and Sovbetov and Saka (2018) have studied the relationship between CDS of the emerging markets and changes in sovereign notation and found that the spread of CDS responds to changes in sovereign ratings. These authors have also evinced that the positive signals add new information on markets, against the negative news which is expected, and therefore reflected in CDS spreads. These results are contradictory to those found in the previous studies having stated that the negative signals of negative ratings have more effect on CDS spreads. For instance, Norden and Weber (2004) and Salvador (2017) mention that the negative signals greatly expand CDS spreads for issuers of investment grade, while the strong positive signals significantly expand CDS spreads for speculativegrade issuers.

Similarly, Sovbetov and Saka (2018) have studied the interaction between credit risk swaps and domestic stock indexes. It has shown that any increase in the CDS entails a
Analysis of liquidity in emerging bond market

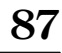


JEFAS 27,53

reduction in the stock market index in the short and long terms, respectively, and vice versa. In fact, he also found that the stock market index and the CDS deviate too much and converge towards a long-term equilibrium at a moderate monthly rate.

Owing to the role of credit rating agencies in the sovereign debt crisis in the financial phase (2007-2008) of the current crisis, as in the Asian crisis of 1997, many criticisms are made due to the sovereign debt crisis, notably from investors affected by the performance of certain financial assets having the best ratings. For structured products, lots of tranches rated AAA has thus experienced large losses because of the shortcomings of the methodology of some agencies. Since the beginning of the public debt crisis, a variety of questions about the practices of these agencies have been raised. They focus mainly on the amplifying effects of their decisions, and even on their legitimacy to record sovereign debts (Alsakka et al., 2014).

Several proposals have been made to address the above-mentioned problems, especially in Europe, where the sovereign debt crisis has been aggravated by the accentuation of ratings on certain economic trends such as the indebtedness of Member States.

This study first directly tests the information content of bond rating announcements and their effect on bond market liquidity.

Next, it investigates the impact of rating changes on sovereign bond liquidity around the rating announcements. Rating changes can affect the sovereign bond price, trading and liquidity around the announcement date. In particular, the rating changes that move the bonds out of the investment-grade category can elicit selling pressure or even fire sales of the fallen angels.

To meet our objectives, our study expresses the impact of changes in sovereign credit ratings on the liquidity of financial markets in emerging economies, mainly during the sovereign debt crisis.

The rest of the paper is organized as follows. Section 2 reviews the relevant literature. Section 3 discusses the data and methodology. Section 4 presents the empirical results, and section 5 concludes the paper.

\section{Literature review}

Generally, the role of rating agencies, as expressed by the new notes, could be a factor in the price volatility of sovereign bonds (Voorhees, 2011). The rating is considered as a new information transmission channel on the market since it reduces the information asymmetry so that asset prices in the market are moving in the direction of the appreciation expressed (Pagano and Volpin, 2010; Deb et al., 2011; Freixas and Laux, 2012).

Recent literature has shown that the role of rating agencies is to provide information on the market through the publication of a note attributed to the situation of an investor (e.g. Deb et al., 2011; De Haan and Amtenbrink, 2011; Schroeter, 2011).

Actually, Deb et al. (2011) demonstrated that the information extracted from the assigned ratings could affect the future behaviour of the sovereign issuer whose choice of economic and financial policies can be either confirmed or amended according to the rating, whether positive or negative. The area of credit rating has increased in line with the regulations of supply and demand (He and Xiong, 2012). According to De Haan and Amtenbrink (2011) and Schroeter (2011), this process has addressed more than 150 rating agencies that are widespread all over the world. They think that about 140 agencies are in one country and/or in one oriented sector, while around five to ten ones based in Japan, the USA and Canada provide new assessments whether as a country or industry. The global market is dominated by three major agencies, which are S\&P, Moody's and Fitch. These agencies are dominant in the market with an estimated share of $40 \%$ each to S\&P, Moody's and Fitch $15 \%$. In addition, the number of issuers rated by S\&P increased from 1,386 in 1981 to 5,860 in 2009, with a 
significant increase in revenues. The emergence of new notes is carried away by the strong investor demand in the financial markets for information about issuers of shares and bonds. Schroeter (2011) shows that the novella score gives new information about the issuer of the bond, and the likelihood that the issuer can face these engagements.

The ratings of sovereign debt by the rating agencies are considered as assessments of the default probability of the public debt. Indeed, these agencies use economic and political factors to make a qualitative and quantitative assessment of the asset. Through this process, the change in the rating sovereign debt may give new information on the financial situation of a country, requiring considerable externalities to the private sector of the country, which can appropriate the investors to keep the assets.

\subsection{The effect of the sovereign rating actions on the financial market}

Sovereign ratings are the ratings of the ability and willingness of governments to meet their financial markets (Gusdinar and Koesrindartoto, 2014). These ratings affect the dynamics of capital markets and affect the cost of capital. Brooks et al. (2004) show that the degradation of ratings has a negative effect on the stock markets.

Gande and Parsley (2005) and Ferreira and Gamma (2007) show that the sovereign downgrades have injected new valuable information for the spreads of sovereign bonds and aggregate stock returns of other countries, especially in the emerging economies, countries' neighbours and during times of crisis, for against the improvements they are immaterial.

In their study on the swap market, Ismailescu and Kazemi (2010) show positive signals that had better affected the price of CDS. However, Norden and Weber (2004) have found the results quite inconsistent. These authors find that negative scoring signals have more effect on CDS spreads. However, they find that negative signals significantly expand CDS spreads for issuers of investment grade, and significantly narrower CDS spreads positive announcements for issuers of investment grade.

Kim and $\mathrm{Wu}(2008)$ attempted to examine the role of attracting sovereign ratings S\&P international capital. They find that the new sovereign rating is an important incentive for the three types of international capital flows. Similarly, they find a great evolution of the bond market after the improvement of sovereign ratings. Borensztein et al. (2013) show that the sovereign ratings generally represent a measure of a country's credit risk.

A large literature has shown that the ratings issued by credit rating agencies have an impact on different segments of the financial system (Canh et al., 2021). Indeed, previous studies have found very significant relationships between the bad news provided by the agencies and stock market returns, currency, bond spreads, CDS spreads and volatility in asset prices, while the good news has an insignificant or limited impact (e.g. Kaminsky and Schumkler, 2002; Afonso et al., 2012; Alsakka and Ap Gwilym, 2012).

Afonso et al. (2014) show that in moments the stock yields, currencies and sovereign bonds are highly correlated with the new credit quotes, particularly bad news. Several studies have shown that the sovereign ratings granted by the rating agencies generate cross-border effects (Gande and Parsley, 2005; Ferreira and Gama, 2007; De Santis, 2012), and others have found that there is a correlation of cross-country in the stock and bond markets (Christopher et al., 2012).

Investors on the market must distinguish between the credit ratings granted by the different credit rating agencies. However, Afonso et al. (2012) find in their study comparing the rating agencies, the obligations of credit spreads react significantly with S\&P announcements, while for Moody's and Fitch advertisements have limited information content on the market. In addition, Alsakka and ApGwilym (2012) find that a number of empirical studies have shown that the prospect signals are less important than the actual rating changes in terms of the impact on financial markets. 
JEFAS

27,53

90

\section{Method}

\subsection{Data and procedures}

The sample includes daily data on sovereign bonds that go from July 2009 to July 2017.

Our sample includes more than 140 bonds issued by the following emerging markets: Argentina, Mexico, Peru, Hungary, Greece, Poland, Spain, Turkey and Hong Kong. We used daily data from July 2009 to July 2017, for the empirical configurations, which is historically limited by the availability of data on the bid-ask spread, Datastream. We obtained the assessments of these obligations of the Fitch Ratings rating agency. Then, we converted the ratings assigned to numbers from 23 (AAA) to 1 (D). For the remaining variables, data is extracted from the database Datastream (see Table 1). Further, rating collected is shown in Table 2.

This study aims to question the sources of the liquidity problem of sovereign bonds issued by emerging countries. Our database consists of daily data of all nine emerging countries for the period from July 2009 to July 2017. Panel data were collected from the Datastream database.

To determine the factors explaining the lack of liquidity in the emerging bond markets, we used panel data as a technique for econometric analysis. Indeed, Greene, 2003 has defined panel data as a technique that uses cross-sectional data from the time domain to predict economic relations.

Similarly, Wooldridge (2002) shows that the panel uses the effects of cross-sections. Thus, the analysis makes use of data, which has both time and the number of bonds. Among the reasons why this technique was preferred over other techniques is that the technology allows us to control the secret effects that may be related to the parameters in the model of liquidity. In addition, we expect that the modelling of financial data is set so that it will have both the time dimension and the number of bonds dimension leading us to more accurate results.

Indeed, the use of panel data is preferable to the use of time-series data and the cross. First, in the panel data analysis, we do not meet the compliance deficiency problem that is common in many time-series and analysis sections. In addition, Sun and Parikh (2001) show that the observations collected during a period are arranged and the number of observations increases.

Similarly, Hsiao et al. (1999) demonstrates that the range of data reduces the interaction between the variables and parameters that will be more reliable. This improves the variation and the flow of information. In addition, the panel data could be used to analyse an infinite number of complex models concerning the time-series analysis and the analysis of the crosssection. However, Baltagi (2001) and Balestra and Nerlove (1992) demonstrated that the use of panel data reduces several estimation problems such as accurate autocorrelation (Bayrakdaroglu et al., 2013).

The Hausman specification test has been used to choose between the methods of analysis or the fixed effect model or the random effects model. Regarding this hypothesis H0 states that "random effects exist" and the hypothesis H1 states "random effects do not exist".

\begin{tabular}{lcccc}
\hline Variable & Mean & Std. Dev. & Min & Max \\
\hline Liq & -0.0257058 & 0.320645 & -2.23924 & 1.023867 \\
Cr & 17.3497 & 3.861531 & 8 & 23 \\
Vol & 0.0236286 & 0.0435627 & 0.0001576 & 0.9374187 \\
$\mathrm{Ai}$ & -0.327245 & 10.4252 & -116.2 & 37 \\
Age & 7.023585 & 7.24137 & -10.9116 & 37.0422 \\
Coup & 10.07584 & 5.437586 & -1.9871 & 17.7465 \\
Ir & 7.462716 & 10.60874 & 0.015 & 74.3
\end{tabular}

Table 1. Note(s): Age: Age of bonds; Ai: Asymmetric information; Coup: Coupon; Cr: Credit Rating; Ir: Interest Rate; Descriptive statistics of Liq: liquidity; Vol: Volatility (these variables will be defined later) 




Analysis of liquidity in emerging bond market

91

Table 2.

Descriptive statistics of the rating collected 
JEFAS

27,53

92

HO. Absence of fixed effects: when the probability is greater than $5 \%$.

H1. Presence of fixed effects: when the probability is less than $5 \%$.

That is, if the probability is less than $5 \%$, we use the fixed effect, and if it is bigger, the random effect is issued. Indeed, the results presented in Table 4 show that the hypothesis H0 is rejected for the lever models with the $1 \%$ level of significance, so note the very individual effect on the total lever models is random but are fixed. In other words, hypothesis H1 expresses the fixed effects model is more effective than the random effects model. In addition, the fixed effects model in this study analyses regression panel data.

\subsection{Econometric estimation}

The model is given by:

$$
L_{i q} q_{i t}=\alpha_{0}+\alpha_{1} C R_{i t}+\alpha_{2} \operatorname{Vol}_{i t}+\alpha_{3} A I_{i t}+\alpha_{4} \operatorname{Coup}_{i t}+\alpha_{5} \text { Age }_{i t}+\alpha_{6} I R_{i t}+\varepsilon_{t}
$$

where, $L i q_{i t}$ : Liquidity of the bond $i$ at time $t$;

$C R_{i t}$ : Credit rating announcement of bond $i$ at time $t$;

$V_{o l}$ : Volatility of price of the bond $i$ at time $t$;

$A I_{i t}$ : Asymmetric information between investors;

Coup $i t$ : Coupon of bond;

Age $i t$ : Age of the obligation; and

$I R_{i t}:$ Interest rate.

\subsection{Variables}

Liquidity. This is considered central to the functioning of the financial markets. Indeed, structural changes in the financial systems that have been ongoing for some time have increased the importance of market liquidity. The literature provides a menu of measures and considers proxies to estimate the liquidity of the emerging markets. Lesmond (2005) expresses five different proxies for the liquidity measure. The first one expresses the bid-ask spread costs and the Commission. This measure is expressed as follows:

Quoted Spread $_{Q}=1 / 2[(A Q-B Q) /(A Q+B Q) / 2+(A Q-1-B Q-1) /(A Q-1+B Q$

$$
-1) / 2]
$$

Saadaoui and Boujelbene (2014) express this measure differently:

$$
\text { Liq }=\left[\left(A_{t}-B_{t}\right) /\left(A_{t}+B_{t}\right)+\left(A_{t-1}-B_{t-1}\right) /\left(A_{t-1}+B_{t-1}\right)\right]
$$

The second measure is expressed by turnover. It is expressed as follows:

$$
1 / D q \sum_{1}^{q} \text { Volume t/Share Outstanding }
$$

where $D_{Q}$ is the number of days in the quarter, $Q$.

The third one expresses this measurement given by Amihud (2002). In fact, the measure is expressed as follows: 


$$
1 / D q \sum_{1}^{Q}|R| /(\text { Price } t * \text { Volume } t)
$$

Analysis of liquidity in emerging bond market

The fourth one expresses the extent of Roll (1984). In fact, we tried to use another measure that is used by Dastidar and Phelps (2009), and that expresses the cost of liquidity score:

$$
L C S=\left\{\begin{array}{c}
(\text { Bid }- \text { Ask }) \text { Spread } * O A S D \rightarrow \text { if bond is spread coted } \\
\frac{(\text { Ask Price }- \text { Bid Price })}{\text { Bid Price }} \rightarrow \text { if bond is price coted }
\end{array}\right.
$$

The choice of a liquidity model in the interest rate markets will ultimately depend on the data available, such as Liquidity Cost Scores (LCS) for our purposes. Although the LCS does not directly account for the price impact for large orders, Dastidar and Phelps (2009) find that it is strongly correlated with the price impact. The LCS seems persistent on average: bonds with a low LCS should remain liquid for a long time according to the LCS measure.

Credit rating. This explanatory variable expresses the quality of the borrower. Several measures for this variable differ from one author to another. This variable is expressed by the rating that reflects the credit quality of the borrower in the form of notations that differ from one agency to another. The three main rating agencies are the following: Fitch, Moody's and S\&P. The notations used by these three agencies are detailed in Table 3. These notations are

\begin{tabular}{lll}
\hline Fitch & Moody's & S\&P's \\
\hline AAA & Aaa & AAA \\
AA+ & Aa1 & AA+ \\
AA & Aa2 & AA \\
AA- & Aa3 & AA- \\
A+ & A1 & A+ \\
A & A2 & A \\
A- & A3 & A- \\
BBB + & Baa1 & BBB+ \\
BBB & Baa2 & BBB \\
BBB- & Baa3 & BBB- \\
BB+ & Ba1 & BB+ \\
BB & Ba2 & BB \\
BB- & Ba3 & BB- \\
B+ & B1 & B+ \\
B & B2 & B \\
B- & B3 & B- \\
CCC + & Caa1 & CCC+ \\
CCC & Caa2 & CCC \\
CCC- & Caa3 & CCC- \\
CC & Ca & CC \\
C & C & C \\
DDD & & SD \\
DD & & D \\
D & &
\end{tabular}

Source(s): Own elaboration

Table 3. The notations used by the three rating agencies 
JEFAS 27,53

\section{4}

transformed linearly in a digital form, as shown in Cantor and Packer (1996). The ratings after transformation are displayed in Table 4.

Information asymmetry is an explanatory variable that expresses the existing asymmetry between the seller and the buyer of a product or asset. On the credit market, banks give loans, and they do not know the risks associated with some loans that they give. On the contrary, borrowers know how likely the success of their projects is. This allows banks to raise interest rates on loans granted, and essentially to risky borrowers. Therefore, there are two situations: the first is the extant risk, which is determined at the time of signing the contract. The second one is the ex-post risk that emerges after the purchase or signing of the contract.

Volatility. Volatility can be expressed as a measure of the variance of a security, an index relative to its average price. It, therefore, measures the historical variation in the price of a bond. It can be assessed over a short, medium or long history. Considered in finance as the basis for measuring risk, volatility is a measure of the amplitudes of changes in the price of a financial asset.

Thus, the higher the volatility of an asset is, the more the investment in this asset will be considered risky, and therefore the higher the expectation of gain (or risk of loss) is.

Conversely, a risk-free or very low-risk asset will have very low volatility because its repayment is almost certain. Actually, the volatility of a bond corresponds to the evolution of the price following a variation of $1 \%$ in interest rates. Commonly used to designate short-term oscillations of a financial asset, the concept of volatility concerns all horizons (short, medium and long term) and does not care about the direction of movement (only the amplitude of movements is taken into account).

\begin{tabular}{|c|c|c|c|c|c|}
\hline \multicolumn{2}{|l|}{ Fitch(*) } & \multicolumn{2}{|c|}{ Moody's } & \multicolumn{2}{|c|}{ S\&P's } \\
\hline AAA & 23 & Aaa & 20 & AAA & 22 \\
\hline $\mathrm{AA}+$ & 22 & Aa1 & 19 & $\mathrm{AA}+$ & 21 \\
\hline $\mathrm{AA}$ & 21 & $\mathrm{Aa} 2$ & 18 & $\mathrm{AA}$ & 20 \\
\hline AA- & 20 & $\mathrm{Aa} 3$ & 17 & AA- & 19 \\
\hline $\mathrm{A}+$ & 19 & $\mathrm{~A} 1$ & 16 & $\mathrm{~A}+$ & 18 \\
\hline A & 18 & $\mathrm{~A} 2$ & 15 & A & 17 \\
\hline A- & 17 & A3 & 14 & A- & 16 \\
\hline $\mathrm{BBB}+$ & 16 & Baal & 13 & $\mathrm{BBB}+$ & 15 \\
\hline BBB & 15 & Baa2 & 12 & $\mathrm{BBB}$ & 14 \\
\hline BBB- & 14 & Baa3 & 11 & BBB- & 13 \\
\hline $\mathrm{BB}+$ & 13 & $\mathrm{Ba} 1$ & 10 & $\mathrm{BB}+$ & 12 \\
\hline $\mathrm{BB}$ & 12 & $\mathrm{Ba} 2$ & 9 & $\mathrm{BB}$ & 11 \\
\hline BB- & 11 & $\mathrm{Ba} 3$ & 8 & $\mathrm{BB}-$ & 10 \\
\hline $\mathrm{B}+$ & 10 & B1 & 7 & $\mathrm{~B}+$ & 9 \\
\hline B & 9 & $\mathrm{~B} 2$ & 6 & B & 8 \\
\hline B- & 8 & B3 & 5 & B- & 7 \\
\hline $\mathrm{CCC}+$ & 7 & Caa1 & 4 & $\mathrm{CCC}+$ & \\
\hline $\mathrm{CCC}$ & 6 & Caa2 & 3 & CCC & 5 \\
\hline CCC- & 5 & Caa3 & 2 & $\mathrm{CCC}-$ & 4 \\
\hline $\mathrm{CC}$ & 4 & $\mathrm{Ca}$ & 1 & $\mathrm{CC}$ & \\
\hline $\mathrm{C}$ & 3 & $\mathrm{C}$ & 0 & $\mathrm{C}$ & 2 \\
\hline DDD & 2 & & & SD & 1 \\
\hline DD & 1 & & & $\mathrm{D}$ & \\
\hline $\mathrm{D}$ & 0 & & & & \\
\hline \multicolumn{6}{|c|}{ Note(s): (*) Data extracted from Fitch rating } \\
\hline
\end{tabular}

Note(s): (*) Data extracted from Fitch rating
Table 4.

The linearly transformed digital form of the notations 
The volatility of a bond is calculated, using the standard deviation formula:

\section{Analysis of liquidity in emerging bond market}

Asymmetric information. Information asymmetry occurs when some investors have more information than others. In fact, this asymmetry hardly causes problems linked to antiselection and moral hazard in the event of negotiation (Akerlof, 1970). Verecchia (2001) shows that in order to mitigate the risk, uninformed investors reduce the price they are willing to pay for a bond or increase the asking price to sell it to minimize the spread between supply and demand for asset prices.

Several empirical studies conducted since the 1960s have indicated the relationship of the bid-ask spread, or simply the spread, with liquidity in trading assets and with information received by the market. The first analyses of the determinants of the bid-ask spread on the bond market followed the founding article by Demsetz (1968). However, Aitken and Frino (1996) use the median spread in the calculation to alleviate the problems caused by the bid-ask rebound, as there are sometimes quoted supply and demand changes that are quickly reversed.

Indeed, other studies in the 1990s have used the intraday spread. The main justification for this methodology is the objective of the analysis, which focused on models for the propagation of Intraday volumes (Lee et al., 1993; McInish and Wood, 1992) and the calculation of liquidity (Fleming, 2003; Fleming and Sarkar, 1999). In addition, other indicators have been used in the research to estimate information asymmetry: the probability of informed trading (PIN), market liquidity and bond volatility. Indeed, according to subsequent studies, the bid-ask propagation is the most frequently used measure of information asymmetry in university research. Due to its measurement characteristic, the bid-ask spread reflects the uncertainty in the value of the asset, and the greater the uncertainty is, the greater information asymmetry between the parties in a negotiation is. Finally, based on the studies presented above, we can say that the bid-ask gap is an adequate indicator of information asymmetry. Indeed, the formula that we used is expressed as follows:

$$
S_{i, t}=\sum\left(P_{i, t}^{a}-P_{i, t}^{b}\right) / \sum P m_{i, t}
$$

where $P_{i, t}{ }^{a}=$ quoted ask in time period $t$ of bond $i ; P_{i, t}{ }^{b}=$ quoted bid in time period $t$ of bond $i ; P m_{i, t}=$ midpoint spread in time period $t$ of bond $i$ and $S_{i, t}=$ average daily bidask spread in time period $t$ of bond $i$. The midpoint spread $\left(P m_{i, t}\right)$ is given by $\left(P_{i, t}{ }^{a}-P_{i, t}{ }^{b}\right) / 2$.

Age. Age is considered as one of the main characteristics of the bond ranging from a few months to 50 years before the capital is repaid. Over this period, the risk is greatly high as there is more chance that the bond will be sold before maturity if it is remote.

Coupon. The issuer offers the interest to the investor as compensation for the duration of the loan. It is expressed as a percentage of per-value. In principle, the amount of the coupon is more than the issuer of lesser quality, and the loan is long term. Conversely, an issuer of good quality, short-term securities borrows to offer a lower coupon. The coupon may be fixed or variable. It is mostly paid on an annual basis, but bonds may pay coupons that are more regular on a half-yearly or quarterly basis, for example. The coupons will depend on the duration of the obligation and the quality of the issuer. 
JEFAS

27,53

96
Some obligations do not pay a coupon during the life of the loan. This is called bonds "zero-coupon".

Interest rate. Investing in bonds has long been considered one of the safest, especially if you hold the securities until maturity. However, there are some risks.

The sovereign debt crisis of 2011-2012 reminded us that even the supposedly safest bonds, namely those of governments, could present risks. The long period of very low interest rates that we have known for several years has reduced the attractiveness of bond investments while placing additional risk on bond holders. Interest rates measure the value of a bond. They can increase or decrease, and thus invest in bonds more or less attractive when compared to the value of the coupon. If rates go up, the price of an already issued bond decreases (investors prefer to place at higher rates, so resell the bonds they hold, which pushes their price down. Thus, already issued bonds offer the same return as the market). Conversely, if rates fall, the value of the bond rises. These movements have no consequences for investors who keep their bonds until maturity, since they will be redeemed at their original value.

\section{Results}

\subsection{Correlation analysis}

Before beginning the regression of the panel data, it is necessary to examine the correlations between the explanatory variables used in our econometric model. The aim is to avoid the biases of multi-collinearity. The latter can induce instability of the regression coefficients and distort the precision of the model estimate. Table 5 shows the correlation coefficients between the different variables considered in our study.

Before interpreting the results of the estimation, it is interesting to study the problem of multi-collinearity between the explanatory variables. Reading the correlation matrix reveals that the correlation coefficients between the independent variables have a minimum value of -0.4575 and a maximum of 0.4203 . This leads us to note the absence of the problem of multi-collinearity between these variables insofar as no coefficient exceeds the limit value of 0.7 . This shows that the estimate of the regression coefficients of our model is reliable and valid.

\subsection{Regression analysis}

This paper examines the effect of credit rating announcement on bond liquidity, using the panel data methodology over 2009-2017 across nine countries such as Argentina, Poland,

\begin{tabular}{|c|c|c|c|c|c|c|c|}
\hline & LIQ & $\mathrm{CR}$ & VOL & $\mathrm{AI}$ & AGE & COUP & IR \\
\hline LIQ & 1.0000 & & & & & & \\
\hline $\mathrm{CR}$ & -0.2014 & 1.0000 & & & & & \\
\hline VOL & 0.0945 & -0.0869 & 1.0000 & & & & \\
\hline $\mathrm{AI}$ & -0.344 & 0.1741 & -0.0803 & 1.0000 & & & \\
\hline AGE & 0.4055 & 0.0920 & -0.3716 & -0.4115 & 1.0000 & & \\
\hline COUP & 0.3806 & -0.1044 & -0.2900 & -0.4575 & 0.4203 & 1.0000 & \\
\hline IR & -0.0072 & 0.0265 & -0.0707 & 0.0091 & -0.2136 & -0.0453 & 1.0000 \\
\hline
\end{tabular}

Note(s): AGE: Age of bonds; AI: Asymmetric information; COUP: Coupon; CR: Credit Rating; IR: Interest Rate;

Table 5.

LIQ: liquidity; VOL: Volatility

Correlation matrix

\section{Source(s): Own elaboration}


Greece, Mexico, Peru, Hong Kong, Spain, Hungary and Turkey. Table 6 presents results derived from this analysis.

According to our results, we observe that the information value of the credit rating agency is a contentious and not determinative issue. We also find that the change in ratings has a significant effect on the liquidity of bonds. These results are in line with the findings of previous research of Weinstein (1977), Pinches and Singleton (1978), Kaplan and Urwitz (1979) and Wakeman (1981).

Several empirical studies on the significance of credit notifications on bond or equity returns have found antonymous results. Some studies have studied the change in the price of corporate bonds during the period around the announcement of a rating change, and they have suggested that the stock market has no significant reaction to these notifications. Other studies have established evidence that credit notifications provide a market information value.

We have tried to explain the effect of credit notifications on the liquidity of emerging bond markets, essentially in the post-crisis period. Indeed, the tables show that credit notifications have a significant effect on the liquidity of bonds. This significant effect may be positive for Poland, Mexico, Peru, Hong Kong, Hungary and Turkey, and negative for Argentina, Greece and Spain depending on the sign of the rating awarded by the rating agencies. The negative effect is explained by the degradation of the rating attributed by the rating agency, and this is explored in the results found concerning Greece and Spain where we found that the change of notation to a negative effect and significant is at the $1 \%$ level. This negative effect can be explained by the critical situations that Greece and Spain have seen from the beginning of 2010. These negative effects can be explained by the economic problems and the financial problems that have occurred in these two countries and which led to the intervention of the European Union to stabilize the financial and economic situation of Greece. These results confirm the real situation that these two countries have seen essentially in this period may explain the informational content of the notifications granted by the rating agencies. Our results also show that rating agencies have taken into account the criticisms expressed by several market participants regarding their strategies and the indicators used in the ratings given to financial assets. From the results found, it can be said that liquidity is also an important factor explaining bond spreads, after having neutralized the impact of credit ratings, maturities and volatility. These results indicate that liquidity is indeed taken into account in the valuation of bonds. Liquidity is a concept strongly depending on information transparency. Indeed, the presence of information asymmetry between investors makes trading in the market unclear and results in a reduction in liquidity in the market (Bagehot, 1971; Myers and Majluf, 1984). This theoretical observation may have an effect on the quality of the information disclosed by the various rating agencies, which must show a practical interest for the managers of these agencies. They can seize the opportunity to improve their information disclosure policy in order to reduce information market asymmetries, increase investor confidence and increase the number of transactions in bond securities. Indeed, our results clearly explain this positive relationship between information asymmetry and the liquidity of bonds.

Our results confirm the work of Petersen and Plenborg (2006), which denote that the high quality of disclosed announcement decreases information asymmetries on the market, increases investor authority and appreciates the liquidity of securities. This is explained by the significant effect of the asymmetry of information on the liquidity of the bond markets. Indeed, the more relevant and reliable the quality of the information disclosed by rating agencies is, the greater the liquidity of the securities is.

Our results also show that the control variables used in our model, and which represents the main characteristics of the bonds, have a significant effect on the liquidity of the bonds and essentially on the interest rate. The latter clearly expressing the financial behaviour of
Analysis of liquidity in emerging bond market 
JEFAS

27,53

98 s

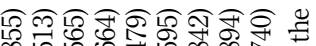

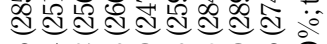

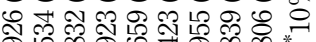


○े



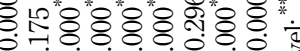

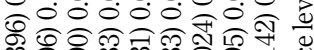

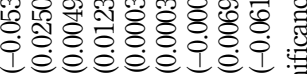
reage o

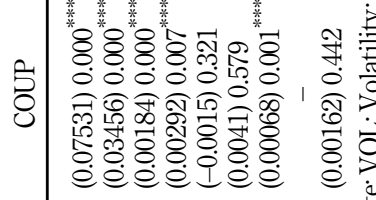

둰

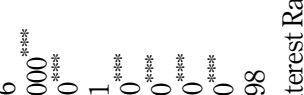

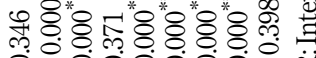

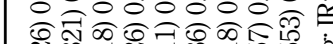

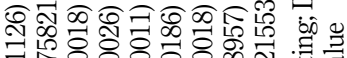


lelelelee

窇要 نे

४

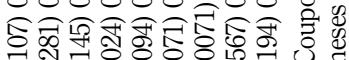
त 0.0 .8 .0 .00



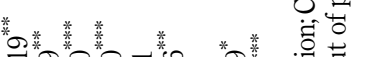

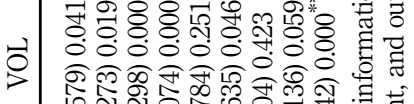

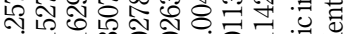

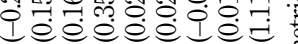
造

* * * * * 先声 *8: 8 \%

원

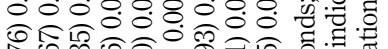
চ 证



Table 6.

Credit rating announcement and bond liquidity 
investors in the market suggests that the two factors price and actuarial rate of return are linked but vice versa. Indeed, the reality of the market imposes those investors to opt for the most profitable investments. Therefore, if interest rates rise, the investor will have an interest in selling their bond in order to invest in another, and if all other things are equal, there will be a fall in bond prices. Moreover, in the event of falling in interest rates, the price of the bond increases. Indeed, the age of a bond or what can be described as its time can indicate its level of liquidity. Indeed, this characteristic is negatively related to liquidity. Thus, the older a bond is or the longer it has been issued, the less liquid it will be. This is well expressed in our results for Greece and Spain during the period of the sovereign debt.

\subsection{Robusteness checks}

We will carry out a robustness test to have the effect of the announcement of rating agencies on the liquidity of emerging bond markets, and we will use an alternative method of estimating the long-term relationship DOLS (Dynamic Ordinary Least Squares). This method is based on a parametric procedure proposed by Saikkonen (1991) and Stock and Watson (1993) in the case of time series. It consists in including advanced and delayed values of the explanatory variables in the co-integration relation, in order to eliminate the nuisances linked to endogeneity and the serial correlation of the residuals.

Table 7 shows that the results of the DOLS estimates confirm the results obtained by the panel data approach. The coefficients are very close and in the case of the DOLS estimates we obtain a significant coefficient for the age variable.

\section{Discussion and conclusions}

Since the role of credit rating agencies in the sovereign debt crisis in the financial phase (2007-2008) of the current crisis is degrading, a lot of criticism was voiced against rating agencies, investors affected by the performance of certain financial assets that had the best ratings. This work examines the information value of local sovereign credit rating announcements in emerging countries. We analyse the effect of sovereign bond ratings on the liquidity of emerging bond markets.

This research aims to present data on the prices of sovereign bonds that react to changes in credit rating by studying the price movements around the announcement of changes in credit rating. The literature is very rich in studies on credit rating changes on stocks and corporate bonds, but this study is perhaps the first attempt on sovereign bonds.

The results of the empirical study indicate that ratings are comparable to signals, conveying information to investors on the bond market. Indeed, our results show that the notifications given by the rating agencies send signals on the liquidity of the bonds; the rating is a means for the investors to convince the market, to attract the providers of funds, and to finance at a lower cost. Similarly, our results show that the agencies give scores on a standardized scale; the informational content of the signals issued depends on the nature of the advertisement and its intensity.

This study can give investors certain assurances of being more courageous when investing in newly rated sovereign bonds. The new and affirmative notes are informative events based on our results. The certification role of credit rating agencies will help less knowledgeable investors who lack the skills and resources to assess credit risk and make better investment decisions. Credit rating announcements reduce asymmetric information between issuers and investors. In this regard, this study attempts to bridge the gap between theory and practice. Therefore, it is significant to consider the impact of rating announcements and the factors influencing bond yields as reliable and informative instruments for investment decisions. 
JEFAS

27,53

100

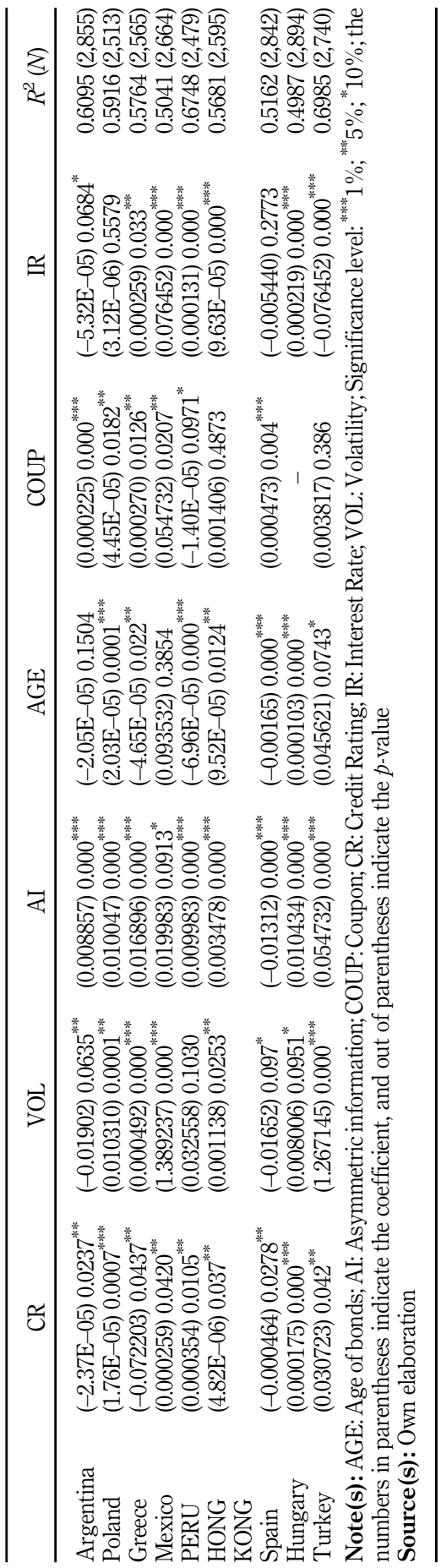

Table 7.

Robustness check using DOLS method 
There are certain limitations to this research. The sample size is small because the announcement of rating changes is not as important as in the bond market. And, as for future research, we can introduce other factors such as that of COVID-19 to test the effect of credit announcements on the liquidity of the bond markets, and we can make a comparison with those of the stock and oil markets.
Analysis of liquidity in emerging bond market

\section{References}

Afonso, A., Furceri, D. and Gomes, P. (2012), "Sovereign credit ratings and financial markets linkages: application to European data", Journal of International Money and Finance, Vol. 31 No. 3, pp. 606-638.

Afonso, A., Gomes, P. and Taamouti, A. (2014), "Sovereign credit ratings, market volatility, and financial gains", Computational Statistics and Data Analysis, Vol. 76, pp. 20-33.

Aitken, M. and Frino, A. (1996), "The accuracy of the tick test: evidence from the Australian stock exchange", Journal of Banking and Finance, Vol. 20 No. 10, pp. 1715-1729.

Akerlof, G. (1970), "The market for 'lemons': quality uncertainty and the market mechanism”, The Quarterly Journal of Economics, Vol. 84 No. 3, pp. 488-500.

Alsakka, R. and Ap Gwilym, O. (2009), "Heterogeneity of sovereign rating migrations in emerging countries", Emerging Markets Review, Vol. 10 No. 2, pp. 151-165.

Alsakka, R. and Ap Gwilym, O. (2012), "Foreign exchange market reactions to sovereign credit news", Journal of International Money and Finance, Vol. 31 No. 4, pp. 845-864.

Alsakka, R., Ap Gwilym, O. and Vu, T.N. (2014), "The sovereign-bank rating channel and rating agencies' downgrades during the European debt crisis", Journal of International Money and Finance, Vol. 49 No. Part B, pp. 235-257, doi: 10.1016/j.jimonfin.2014.03.012.

Amihud, Y. (2002), "Illiquidity and stock returns: cross-section and time-series effects", Journal of Financial Markets, Vol. 5 No. 1, pp. 31-56.

Andreasen, E. and Valenzuela, P. (2016), "Financial openness, domestic financial development and credit ratings", Finance Research Letters, Vol. 16, pp. 11-18.

Bagehot, W. (1971), "The only game in town”, Financial Analysts Journal, Vol. 27 No. 2, pp. 12-14.

Balestra, P. and Nerlove, M. (1992), "Formulation and estimation of econometric models for panel data", in The Econometrics of Panel Data, Springer, Dordrecht, pp. 3-18.

Baltagi, B.H. (2001), Econometric Analysis of Panel Data, 2nd ed., John Wiley \& Sons, Chichester.

Bannier, C.E. and Hirsch, C.W. (2010), "The economic function of credit rating agencies - what does the watch list tell us?", Journal of Banking and Finance, Vol. 34 No. 12, pp. 3037-3049.

Bayrakdaroglu, A., Ege, I. and Yazici, N. (2013), "A panel data analysis of capital structure determinants: empirical results from Turkish capital market", International Journal of Economics and Finance, Vol. 5 No. 4, pp. 131-140.

Böninghausen, B. and Zabel, M. (2015), "Credit ratings and cross-border bond market spillovers", Journal of International Money and Finance, Vol. 53, pp. 115-136.

Borensztein, E., Cowan, K. and Valenzuela, P. (2013), "Sovereign ceilings 'lite'? The impact of sovereign ratings on corporate ratings", Journal of Banking and Finance, Vol. 37 No. 11, pp. 4014-4024.

Brooks, R., Faff, R., Hillier, D. and Hillier, J. (2004), "The national market impact of sovereign rating changes", Journal of Banking and Finance, Vol. 28 No. 1, pp. 233-250.

Canh, N.P., Schinckus, C., Su, T.D. and Chong, F.H.L. (2021), "Institutional quality and risk in the banking system", Journal of Economics, Finance and Administrative Science, Vol. 26 No. 51, pp. 23-40. 
JEFAS

27,53
Cantor, R. and Packer, F. (1996), "Determinants and impact of sovereign credit ratings", Federal Reserve Bank of New York Quarterly Review, October, pp. 37-51.

Chodnicka-Jaworska, P. (2017), "The effect of countries' credit ratings on credit default swap spreads", in Raczkowski, K. (Ed.), Risk Management in Public Administration, pp. 71-92.

Christopher, R., Kim, S.J. and Wu, E. (2012), "Do sovereign credit ratings influence regional stock and bond market interdependencies in emerging countries?", Journal of International Financial Markets, Institutions and Money, Vol. 22 No. 4, pp. 1070-1089, doi: 10.1016/j.intfin.2012.01.003.

Dastidar, S. and Phelps, B. (2009), Introducing LCS-Liquidity Cost Scores for US Credit Bonds, Barclays Research.

De Haan, J. and Amtenbrink, F. (2011), "Credit rating agencies”, in Eijffinger, S. and Masciandaro, D. (Eds), Handbook of Central Banking and Financial Regulation after the Financial Crisis, Edward Elgar, Vol. 107, pp. 1-11.

De Santis, R.A. (2012), "The Euro Area sovereign debt crisis: safe haven, credit rating agencies and the spread of the fever from Greece, Ireland and Portugal", Working Paper No: 1419, European Central Bank, papers.ssrn.com, pp. 1-59.

Deb, P., Manning, M., Murphy, G., Penalver, A. and Toth, A. (2011), "Whither the credit ratings industry?", Papers No: 9, Bank of England Financial Stability, papers.ssrn.com, pp. 3-22.

Demsetz, H. (1968), “The cost of transacting”, The Quarterly Journal of Economics, Vol. 82, pp. 33-53.

Duggar, E., Emery, K., Gates, D., Carpenter, A., Lemay, Y. and Cailleteau, P. (2009), Emerging Market Corporate and Sub-sovereign Defaults and Sovereign Crises: Perspectives on Country Risk, Moody's Investors Service, February.

Ferreira, M.A. and Gama, P.M. (2007), "Does sovereign debt ratings news spill over to international stock markets?”, Journal of Banking and Finance, Vol. 31 No. 10, pp. 3162-3182, doi: 10.1016/j. jbankfin.2006.12.006.

Fleming, M.J. (2003), "Measuring treasury market liquidity”, Economic Policy Review, Vol. 9 No. 3, p. 57.

Fleming, M.J. and Sarkar, A. (1999), "Liquidity in U.S. treasury spot and futures markets quality", Working Paper, Federal Reserve Bank of New York.

Freixas, X. and Laux, C. (2012), "Disclosure, transparency, and market discipline", in Dewatripont, M. and Freixas, X. (Eds), The Crisis Aftermath: New Regulatory Paradigms, Centre for Economic Policy Research, London, pp. 69-104.

Fridson, M. and Sterling, K. (2006), "Fallen angels: a separate and superior asset class", The Journal of Fixed Income, Vol. 16 No. 3, p. 22.

Gande, A. and Parsley, D.C. (2005), "News spillovers in the sovereign debt market", Journal of Financial Economics, Vol. 75 No. 3, pp. 691-734, doi: 10.1016/j.jfineco.2003.11.003.

Greene, W.H. (2003), Econometric Analysis, Pearson Education India, New York, pp. 45-97.

Gusdinar, I.A. and Koesrindartoto, D.P. (2014), "Institutional investors trading strategy in Indonesia's government bond market during the 2008 crisis", Asian Academy of Management Journal of Accounting and Finance, Vol. 10 No. 1, pp. 21-44.

He, Z. and Xiong, W. (2012), "Dynamic debt runs", The Review of Financial Studies, Vol. 25 No. 6, pp. $1799-1843$.

Hsiao, C., Pesaran, M.H., Lahiri, K. and Lee, L.F. (Eds) (1999), Analysis of Panels and Limited Dependent Variable Models, Cambridge University Press.

Ismailescu, J. and Kazemi, H. (2010), "The reaction of emerging market credit default swap spreads to sovereign credit rating changes", Journal of Banking and Finance, Vol. 34 No. 12, pp. 2861-2873.

Kaminsky, G. and Schumkler, S.L. (2002), "Emerging markets instability: do sovereign ratings affect country risk and stock return”, World Bank Economic Review, Vol. 16 No. 2, pp. 171-195, doi: 10. 1093/wber/16.2.171. 
Kaplan, R.S. and Urwitz, G. (1979), "Statistical models of bond ratings: a methodological inquiry", Journal of Business, Vol. 52 No. 2, pp. 231-261.

Kim, S. and Wu, E. (2008), "Sovereign credit ratings, capital flows and financial sector development in emerging markets", Emerging Markets Review, Vol. 9 No. 1, pp. 17-39, doi: 10.1016/j.ememar. 2007.06.001.

Lee, C.M., Mucklow, B. and Ready, M.J. (1993), "Spreads, depths, and the impact of earnings information: an intraday analysis", Review of Financial Studies, Vol. 6 No. 2, pp. 345-374.

Lesmond, D.A. (2005), "Liquidity of emerging markets", Journal of Financial Economics, Vol. 77 No. 2, pp. $411-452$.

McInish, T.H. and Wood, R.A. (1992), "An analysis of intraday patterns in bid/ask spreads for NYSE stocks”, The Journal of Finance, Vol. 47 No. 2, pp. 753-764.

Myers, S.C. and Majluf, N.S. (1984), "Corporate financing and investment decisions when firms have information that investors do not have", Journal of Financial Economics, Vol. 13 No. 2, pp. 187-221.

Norden, L. and Weber, M. (2004), "Informational efficiency of credit default swap and stock markets: the impact of credit rating announcements", Journal of Banking and Finance, Vol. 28 No. 11, pp. 2813-2843.

Pagano, M. and Volpin, P. (2010), "Credit ratings failures and policy options”, Economic Policy, Vol. 25 No. 62, pp. 403-431.

Petersen, C. and Plenborg, T. (2006), "Voluntary disclosure and information asymmetry in Denmark", Journal of International Accounting, Auditing and Taxation, Vol. 15 No. 2, pp. 127-149.

Pinches, G.E. and Singleton, J.C. (1978), "The adjustment of stock prices to bond rating changes", The Journal of Finance, Vol. 33 No. 1, pp. 29-44.

Roll, R. (1984), "A simple implicit measure of the effective bid-ask spread in an efficient market", The Journal of Finance, Vol. 39 No. 4, pp. 1127-1139.

Rusike, T.G. and Alagidede, I.P. (2021), "The impact of sovereign credit ratings on Eurobond yields: evidence from Africa", Research in International Business and Finance, Vol. 58, pp. 1-27, 101475.

Saadaoui, A. and Boujelbene, Y. (2014), "Liquidity and credit risk in the emerging financial markets", Public Finance Quarterly, Vol. 592, p. 207.

Saikkonen, P. (1991), "Asymptotically efficient estimation of cointegration regressions", Econometric Theory, Vol. 7 No. 1, pp. 1-21.

Salvador, C. (2017), "Effect of signals of bank ratings on stock returns before and during the financial crisis", The Spanish Review of Financial Economics, Vol. 15 No. 1, pp. 1-11, doi: 10.1016/j.srfe. 2017.01.002.

Schroeter, U.G. (2011), "Credit ratings and credit rating agencies", in Caprio, G. (Ed.), Encyclopedia of Financial Globalization, Elsevier, SSRN 1903670.

Sovbetov, Y. and Saka, H. (2018), "Does it take two to tango: interaction between credit default swaps and national stock indices", Journal of Economics and Financial Analysis, Vol. 2 No. 1, pp. 129-149.

Stock, J.H. and Watson, M.W. (1993), "A simple estimator of cointegrating vectors in higher order integrated systems", Econometrica: Journal of the Econometric Society, Vol. 61 No. 4, pp. 783-820.

Sun, H. and Parikh, A. (2001), "Exports, inward foreign direct investment (FDI) and regional economic growth in China", Regional Studies, Vol. 35 No. 3, pp. 187-196.

Vazza, D., Leung, E., Alsati, M. and Katz, M. (2005), CreditWatch and Ratings Outlooks: Valuable Predictors of Rating Behavior, Global Fixed Income Research, Standard and Poor's and New York.
Analysis of liquidity in emerging bond market 
JEFAS

27,53

104

Verrecchia, R.E. (2001), "Essays on disclosure”, Journal of Accounting and Economics, Vol. 32 Nos 1-3, pp. $97-180$.

Voorhees, R. (2011), "Rating the raters: restoring confidence and account ability in credit rating agencies", Case Western Reserve Journal of International Law, Vol. 44, p. 875.

Wakeman, L.M. (1981), "The real function of bond rating agencies", Chase Financial Quarterly, Vol. 1 No. 1, pp. 18-26.

Weinstein, M.I. (1977), "The effect of a rating change announcement on bond price", Journal of Financial Economics, Vol. 5 No. 3, pp. 329-350.

Wengner, A., Burghof, H.P. and Schneider, J. (2015), "The impact of credit rating announcements on corporate CDS markets - are intra-industry effects observable?", Journal of Economics and Business, Vol. 78, pp. 79-91.

Wooldridge, J.M. (2002), "Further results on instrumental variables estimation of average treatment effects in the correlated random coefficient model”, Economics Letters, Vol. 79 No. 2, pp. 185-191.

\section{Corresponding author}

Amir Saadaoui can be contacted at: am.saadaoui@yahoo.fr

For instructions on how to order reprints of this article, please visit our website:

www.emeraldgrouppublishing.com/licensing/reprints.htm

Or contact us for further details: permissions@emeraldinsight.com 